\title{
Methanol-Tolerant M-N-C Catalysts for Oxygen Reduction Reactions in Acidic Media and Their Application in Direct Methanol Fuel Cells
}

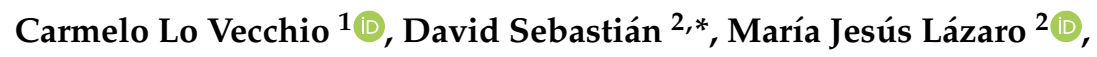 \\ Antonino Salvatore Aricò ${ }^{1}$ (D) and Vincenzo Baglio ${ }^{1, *(D)}$ \\ 1 Institute for Advanced Energy Technologies "Nicola Giordano", CNR-Consiglio Nazionale delle Ricerche, \\ Via Salita Santa Lucia sopra Contesse, 5, 98126 Messina, Italy; lovecchio@itae.cnr.it (C.L.V.); \\ arico@itae.cnr.it (A.S.A.) \\ 2 Institute of Carbochemistry, CSIC-Spanish National Research Council, C/. Miguel Luesma Castán, 4, \\ 50018 Zaragoza, Spain; mlazaro@icb.csic.es \\ * Correspondence: dsebastian@icb.csic.es (D.S.); baglio@itae.cnr.it (V.B.); Tel.: +39-090-624237 (V.B.)
}

Received: 7 November 2018; Accepted: 7 December 2018; Published: 11 December 2018

\begin{abstract}
Direct methanol fuel cells (DMFCs) are emerging technologies for the electrochemical conversion of the chemical energy of a fuel (methanol) directly into electrical energy, with a low environmental impact and high efficiency. Yet, before this technology can reach a large-scale diffusion, specific issues must be solved, in particular, the high cost of the cell components. In a direct methanol fuel cell system, high capital costs are mainly derived from the use of noble metal catalysts; therefore, the development of low-cost electro-catalysts, satisfying the target requirements of high performance and durability, represents an important challenge. The research is currently addressed to the development of metal-nitrogen-carbon (M-N-C) materials as cheap and sustainable catalysts for the oxygen reduction reaction (ORR) in an acid environment, for application in polymer electrolyte fuel cells fueled by hydrogen or alcohol. In particular, this mini-review summarizes the recent advancements achieved in DMFCs using M-N-C catalysts. The presented analysis is restricted to M-N-C catalysts mounted at the cathode of a DMFC or investigated in rotating disk electrode (RDE) configuration for the ORR in the presence of methanol in order to study alcohol tolerance. The main synthetic routes and characteristics of the catalysts are also presented.
\end{abstract}

Keywords: M-N-C catalysts; direct methanol fuel cell; methanol tolerance; oxygen reduction reaction

\section{Introduction}

Direct methanol fuel cells (DMFCs) are promising power supply systems because of their good efficiency and the high energy density of the fuel $\left(6100 \mathrm{mWh}^{-1}\right)$, which for allows prolonged operation [1,2]. A technical drawback to be addressed for the further development of DMFCs is the low power density resulting from the sluggish kinetics of methanol oxidation reactions (MORs) and oxygen reduction reactions (ORRs). Other critical factors are the cost of the anode and cathode catalysts, which are usually based on expensive platinum-group metals (PGMs), and methanol crossover through the polymeric membrane, which creates a mixed potential at the cathode and decreases the overall efficiency [3-6]. Although Pt is very active for the ORR, it also promotes MOR, which means that if methanol and oxygen are present at the cathode, the selectivity toward ORR is lower than $100 \%$.

The development of methanol-tolerant cathode catalysts that are cheaper than Pt for DMFCs has received much attention in the last years [7-10]. One approach to minimize the cathode polarization due to methanol crossover, which reduces the cell voltage by about $0.1-0.2 \mathrm{~V}$, relies on the use of a catalyst selective to ORR. Such a methanol-tolerant catalyst is also required in mixed-reactant DMFCs, 
a concept in which the fuel (methanol) and oxidant (oxygen or air) are mixed together before feeding to the fuel cell [11-13].

In the first phase, transition metal chalcogenides (mainly based on Ruthenium) and Pd-based electrocatalysts were envisaged as possible alternatives to $\mathrm{Pt}$, as they showed a good tolerance to methanol as well as a lower cost compared to $\mathrm{Pt}$ [14-17]. However, because of the increased price of PGMs in the last few years, non-noble-metal/PGM-free electrocatalysts have recently been the object of much attention. These are characterized by their much lower cost than $\mathrm{Pt}$, and by an extraordinarily high selectivity towards the oxygen reduction $[18,19]$.

Among these materials, organometallic macrocycles, in particular transition metal phthalocyanines and porphyrins, have been thoroughly examined in the past for their activity towards ORR. For the practical cathodes of a fuel cell, the macrocycles were supported on carbon powder and were thermally treated (up to $800-900{ }^{\circ} \mathrm{C}$ ), which substantially increased their electrocatalytic activities. Another approach was to disperse these compounds in a convenient substrate, such as in an electron-conducting polymer (polyaniline PAni, or polypyrrole PPy). One of the first ideas was to incorporate a tetrasulfonated cobalt porphyrin (CoTsPP) or a tetrasulfonated iron phthalocyanine (FeTsPc) as a counter-ion during the electropolymerization process of pyrrole $[20,21]$. These modified electrodes displayed a good electrocatalytic activity for the ORR, leading to a four-electron process in an acid medium, but a poor stability [22].

In the last few years, many PGM-free formulations were synthesized and investigated for ORR, showing great activity in the rotating disk configuration compared to Pt catalysts, but the performance, durability, and stability were very low in a complete polymer electrolyte fuel cell (PEFC) [23]. More recently, the $\mathrm{M}-\mathrm{N}-\mathrm{C}$ catalysts ( $\mathrm{M}$ being a transition metal such as $\mathrm{Fe}$ or $\mathrm{Co}$ ) showed great promise owing to their good ORR activity and performance in PEFCs [24-31]. On the other hand, there are only a few reports on the performance results of a DMFC equipped with PGM-free catalysts at the cathode, likely due to the relatively recent research interest in this topic. Here, these papers are reviewed on the basis of their DMFC results; ORR activity, in particular in the presence of methanol; and precursors characteristics of the catalysts.

\section{Synthesis of Noble Metal Free Catalysts}

The synthesis of metal-nitrogen-carbon $(\mathrm{M}-\mathrm{N}-\mathrm{C})$ catalysts usually involves the mixing of a non-PGM transition metal, a nitrogen precursor, and a carbon source. The most investigated metals are $\mathrm{Fe}, \mathrm{Co}$, and $\mathrm{Ni}$, but some attempts to prepare partially oxidized metal ( $\mathrm{Ta}, \mathrm{Ti}, \mathrm{Zr}$, $\mathrm{Hf}$, etc.) carbonitride or oxynitride samples have been carried out by the groups of Ota [32,33], Sakurai [34], and Savadogo [35,36]. However, the latter catalysts were neither investigated for their methanol tolerance properties, nor used at the cathode of a DMFC, thus they will be not discussed in the present review.

In general, the nitrogen precursor mainly involved in a typical M-N-C synthesis is generally inside the structure of some polymers, aromatic heterocyclic molecules, amines, or amides containing double or triple bonds. The carbon source can be included in the nitrogen molecule or mixed with the other precursors. After mixing them, a high temperature treatment, under an inert atmosphere, is necessary in order to obtain the catalytic sites able to perform the oxygen reduction reaction with suitable kinetics.

The main differences among the various preparation procedures rely on the nitrogen precursors used. For instance, phthalocyanine (Pc) was used as a nitrogen and carbon source in several works [37-40]. Baranton et al. [37] studied two designs of electrodes-the conventional dispersion of an iron phthalocyanine catalyst on carbon $(\mathrm{FePc} / \mathrm{C})$ and the molecular dispersion of a tetrasulfonated iron phthalocyanine (FeTsPc) in polyaniline (PAni), an electron conducting polymer. The group of Specchia et al. used the monometallic iron phthalocyanine precursor in a couple of works [38,39]; five bimetallic catalysts were prepared by different combinations of two transition metals ( $\mathrm{Fe}, \mathrm{Co}, \mathrm{Cu}$, and $\mathrm{Zn)}$ phthalocyanine precursors [40]. These authors employed the so-called sacrificial support method (SSM), consisting of the use of a templating agent based on silica, which is removed by hydrofluoric 
acid (HF) after the thermal treatment. This procedure (SSM) was also employed by the groups from the University of New Mexico (USA) and CNR-ITAE Institute (Italy) [41-44]. In their joint papers, they presented results for ORR in RDE and DMFC configurations using non-PGM catalysts based on Fe-N-C derived from different precursors (Fe-aminobenzimidazole (Fe-ABZIM) [41,43], Fe-aminoantipyrine (Fe-AAPyr) [42], and Fe-nicarbazin (Fe-NCB) [44]). In the preparation procedures, at least two thermal treatments were carried out, the first one flowing an inert gas, the second one, after $\mathrm{SiO}_{2}$ leaching, in a reactive $\mathrm{NH}_{3}$ atmosphere $[41,42,44]$. For the Fe-ABZIM catalyst, the influence of the post-treatments on the catalyst activity for ORR was carried out [43]. An additional treatment, with respect to the synthetic procedure used in the literature [41], using $4 \mathrm{M} \mathrm{HNO}_{3}$, was performed in order to remove the iron nanoparticles coated with a graphitic layer (centers for Fenton type radical production). The material was washed and heat-treated for a third time in an atmosphere of $\mathrm{NH}_{3}$. As shown in the paragraph regarding the DMFC results, a higher performance was reached with this further treatment, using the same precursor.

Another class of precursors largely employed for the synthesis of the $\mathrm{Fe}-\mathrm{N}-\mathrm{C}$ or $\mathrm{Co}-\mathrm{N}-\mathrm{C}$ catalysts is based on porphyrins [45-49]. Serov et al. [45] synthesized non-PGM catalysts based on M-tetraphenylporphyrin (TPP) $(\mathrm{M}: \mathrm{Fe}, \mathrm{Co}, \mathrm{Ni}, \mathrm{Cu}, \mathrm{Mn}$, and $\mathrm{Zn}$ ) and iron phthalocyanine (PC). Kong et al. [46] prepared $\mathrm{Co}-\mathrm{N}-\mathrm{C}$ catalysts by mixing etched graphene oxide (GO) sheets with abundant in-plane pores and a porphyrin containing both $\mathrm{Co}$ and $\mathrm{N}$ elements as the doping precursor. Kwak et al. [47] used different ratios of cysteine ( $\mathrm{S}$ and $\mathrm{N}$ source) and iron (III) tetramethoxyphenylporphyrin (FeTMPP) to achieve a porous material, characterized by a different crystallinity, after a thermochemical decomposition at $900{ }^{\circ} \mathrm{C}$ in a $\mathrm{N}_{2}$ atmosphere. In this procedure, a silica material was used to transfer the porous template to the carbon structure. After that, the silica was removedusing HF solution. Olson et al. [48] used 5,10,15,20-tetrakis(4-methoxy-phenyl)-porphyrin cobalt(II) (CoTMPP) as the precursor. Their preparation procedure involved the use of amorphous fumed silica as a templating agent; yet, compared with the other syntheses previously reported based on the SSM, the removal of $\mathrm{SiO}_{2}$ was performed using $\mathrm{KOH}$ instead of HF. A similar preparation procedure was carried out by Piela et al. [49]. It was based on the deposition of a precursor (H2TMPP, CoTPP, 1:1 weight ratio of CoTPP:FeTPP (CoFeTPP), or CoTMPP) on amorphous silica, followed by the pyrolysis step and chemical extraction of the template by $\mathrm{KOH}$.

Zhu et al. [50] introduced a novel class of non-PGM catalysts, $\mathrm{Fe}_{3} \mathrm{C}$ encapsulated in N-doped carbon nanotube/carbon black $\left(\mathrm{Fe}_{3} \mathrm{C} / \mathrm{NCNTs} / \mathrm{C}\right.$ ), where $\mathrm{Fe}_{3} \mathrm{C}$ and carbon nanotubes were formed in situ during the pyrolysis. They synthesized a series of $\mathrm{Fe} / \mathrm{N}$-containing electrocatalysts by pyrolyzing dicyanamide $\left(\left(\mathrm{NCNH}_{2}\right)_{2}\right)$, ferric chloride $\left(\mathrm{FeCl}_{3}{ }^{*} 6 \mathrm{H}_{2} \mathrm{O}\right)$, and carbon black. A similar material based on iron carbide encapsulated in graphitic layers $\left(\mathrm{Fe}_{3} \mathrm{C} / \mathrm{NG}\right.$ ) was fabricated by pyrolysing poly (1,8-diaminonapphthalene) (PDAN), which employed 1,8-diaminonaphthalene (DAN) and $\mathrm{FeCl}_{3}$ as precursors [51]. Yang et al. [52] reported the synthesis of a $\mathrm{Fe}_{3} \mathrm{C} @ \mathrm{~N}-\mathrm{C}$ sample, consisting of $\mathrm{Fe}_{3} \mathrm{C}$ nanoparticles encapsulated in mesoporous $\mathrm{N}$-doped carbon (N-C). The catalyst was synthesized by the pyrolysis of a metal organic framework, MIL-100(Fe), and dicyandiamide under an inert atmosphere, followed by acid leaching, which is useful to remove unstable $\mathrm{Fe}_{3} \mathrm{C}$ species. $\mathrm{Fe}_{3} \mathrm{C}$ nanoparticles were wrapped onto the graphitic carbon layers. Liu et al. [53] obtained a Fe-phenantroline/melamine composite that was carbonized at $700,800,900$, or $1000^{\circ} \mathrm{C}$ in a nitrogen atmosphere. A second heat treatment at $900{ }^{\circ} \mathrm{C}$ under a $\mathrm{N}_{2}$ atmosphere was carried out after acid leaching in order to obtain a $\mathrm{Fe}_{3} \mathrm{C} @ \mathrm{~N}-\mathrm{C}$, characterized by a mesoporous nitrogen-doping carbon nanosheet, in which the iron carbide nanoparticles were encapsulated within the graphitic carbon layers.

Wei at al. [54] synthesized $\mathrm{M}-\mathrm{N}-\mathrm{C}$ catalysts starting from organic aerogels prepared with melamine, formaldehyde, and iron or cobalt salt, followed by carbonization. In another work [55], melamine was used as the precursor of $\mathrm{Fe}-\mathrm{N}-\mathrm{rGO}$ catalysts, together with $\mathrm{FeCl}_{3}$. In this case, $\mathrm{rGO}$, obtained from GO through microwave treatment, was used as the carbonaceous material. Yang et al. [56] prepared a bamboo-like carbon nanotube $/ \mathrm{Fe}_{3} \mathrm{C}$ nanoparticle hybrid nano-electrocatalyst, directly annealing a mixture of Pluronic P123, melamine, and ferric nitrate at $800{ }^{\circ} \mathrm{C}$ in $\mathrm{N}_{2}$. 
In some cases, the effect of an additional phosphorus atom was investigated and was found to be beneficial for the overall activity. Hu et al. [57] reported phosphorus doping into a polyaniline-derived $\mathrm{Fe}-\mathrm{N}-\mathrm{C}$ catalyst, and studied the effect on the electrocatalytic activity for the ORR and at the cathode of a DMFC. For the synthesis of phosphorus doped catalysts, an acidic phosphate ester was added to the precursor. On the other hand, an additional sulfur atom presence was studied by Qiu et al. [58]. They synthesized a nitrogen-sulfur-iron doped porous carbon material (Fe-N-S/C) using pyrolysis at $750{ }^{\circ} \mathrm{C}$ of dicyandiamide and thiourea in an argon atmosphere. The physico-chemical characterization showed that $\mathrm{Fe}, \mathrm{N}$, and $\mathrm{S}$ interacted well in the doped carbon matrix.

Other compounds such as ethylenediaminetetraacetic acid (EDTA) or 2,3,5,6-tetrakis(2-pyridyl) pyrazine (TPTZ) were proposed as nitrogen sources [59-61]. In some cases [59,61], a high surface area oxidized carbon support was used to increase the electrical conductivity; whereas, in another work [60], different types of novel carbon nano-networks (CNNs) were employed.

Park et al. [62] synthesized a nano-sized graphene-derived Fe/Co-N-C catalyst by physical ball-milling, and the subsequent chemical modification of the graphene oxide (bGO). The so obtained bGO was dispersed in an aqueous solution together with nitrogen and metal precursors (i.e., dicyandiamide $\left(\mathrm{C}_{2} \mathrm{H}_{4} \mathrm{~N}_{4}\right)$, cobalt chloride $\left(\mathrm{CoCl}_{2} \cdot 6 \mathrm{H}_{2} \mathrm{O}\right)$, and iron chloride $\left.\left(\mathrm{FeCl}_{2} \cdot 4 \mathrm{H}_{2} \mathrm{O}\right)\right)$. Whereas Mei et al. [63] proposed a nanofibrous $\mathrm{Fe}-\mathrm{N} / \mathrm{C}$ catalyst with a multi-scaled porous structure, prepared via the electrospinning of a polyacrylonitrile (PAN) solution containing $\mathrm{Fe}^{3+}$ incorporated graphitic carbon nitride $\left(\mathrm{Fe}-\mathrm{g}-\mathrm{C}_{3} \mathrm{~N}_{4}\right)$. A Fe-N-graphene compound was synthesized by He et al. [64], starting from a nitrogen-containing resin ( $\mathrm{N}$-resin), poly(acrylonitrile-divinylbenzene-triallyl isocyanurate), iron (II) chloride, and a nitrogen-doped graphene composite. This slurry was heated at $900{ }^{\circ} \mathrm{C}$ under an argon atmosphere for 1 hour. In this case, the majority of the $\mathrm{Fe}-\mathrm{N}$ nanoparticles were enwrapped in the bi-layer nitrogen doped graphene structure.

The polymerization of aniline (PAni) on a carbon surface (Vulcan or Ketjenblack) was reported by Bukola et al. [65]. In a second step, $\mathrm{FeCl}_{3} \cdot 6 \mathrm{H}_{2} \mathrm{O}$ was added to the slurry. Ammonium carbonate was also used as a sacrificial support to prevent the aggregation of PAni. Many other preparation routes, involving different precursors (tetraphthalonitrile (TPN) [66], cobalt(II) meso-tetrakis (4-methoxyphenyl) porphine and vitamin C [67], 2-methylimidazole [68], glucose and dicyandiamide (DCDA) [69], and 11,11'-bis(dipyrido[3,2-a:2', $3^{\prime}$-c]phenazinyl) (bidppz) [70]) and carbonaceous materials (nitrogen-doped graphene aerogel [67], ZIF/rGO [68], etc.) were employed to prepare the $\mathrm{M}-\mathrm{N}-\mathrm{C}$ catalysts. These materials were investigated for ORR in RDE configuration only, addressing also their methanol tolerance properties.

Another interesting approach was proposed by ViJ et al. [71]; they prepared a non-PGM catalyst by pyrolising a hybrid adduct of single walled carbon nanotubes (CNT) and lyophilized hemoglobin $(\mathrm{Hb})$ at $700{ }^{\circ} \mathrm{C}$ under $\mathrm{NH}_{3}$ gas $(\mathrm{CNTHb}-700)$. The $\mathrm{Fe}^{2+}$ ions located in each of four heme groups of an $\mathrm{Hb}$ molecule served as a source of active $\mathrm{Fe}_{5} \mathrm{C}_{2}$ nanoparticle-based catalytic sites; and the polypeptide chains and pyrrolic units of the heme group acted like a precursor for the nitrogen doped $\mathrm{sp}^{2}$ carbon support.

In summary, the $\mathrm{M}-\mathrm{N}-\mathrm{C}$ catalysts were synthesized starting from numerous precursors of metal, nitrogen, and carbon, by optimizing the precursor ratio, metal content, and pyrolysis conditions; these were adapted to each system of precursors. The utilization of sacrificial templates (e.g., based on silica) or particular carbon networks and nanostructures represents another interest in the research of improved catalytic activity through the enhancing the availability of active sites. As can be observed from the analysis of the various precursors used to prepare the $\mathrm{M}-\mathrm{N}-\mathrm{C}$ catalysts, Fe-based materials are the most investigated compounds, as they contribute to a greater extent in accelerating the oxygen reduction reaction, as can be seen in the following section dealing with the electrochemical results. 


\section{Catalytic Activity of M-N-C Catalysts for the ORR in Rotating Disk Electrode (RDE) and DMFC}

\subsection{Oxygen Reduction Reaction with Methanol Tolerance in an Acid Environment for M-N-C Catalysts}

A typical RDE linear sweep voltammetry for the study of the ORR electrocatalytic activity is depicted in Figure 1, with a sigmoidal wave from zero to negative current density values (i.e., faradaic reduction process), approaching a constant current density when scanning the potential towards more negative values. This constant current density is the diffusion limiting current $\left(i_{d}\right)$ as predicted by the Levich equation. The potential at which half of $i_{d}$ is obtained, the so-called half-wave potential $\left(\mathrm{E}_{1 / 2}\right)$, is a parameter generally used to evaluate the electrocatalytic activity of a catalyst. Another common parameter is the onset potential $\left(E_{\text {onset }}\right)$, defined as the potential at which the ORR starts (ignoring the non-faradaic current from double layer capacitance, as evident in Figure 1 for $\mathrm{Fe}-\mathrm{N}-\mathrm{C}$ ). As an example, Figure 1a shows the ORR curves in the absence of methanol for a commercial $\mathrm{Pt} / \mathrm{C}$ catalyst (grey) and a $\mathrm{M}-\mathrm{N}-\mathrm{C}$ catalyst (red), where $\mathrm{E}_{1 / 2}$ and $\mathrm{E}_{\text {onset }}$ are indicated for reference. Figure $1 \mathrm{~b}$ shows the behavior in the presence of methanol $(0.2 \mathrm{M})$, illustrating the changes derived in the ORR for both catalysts. In the case of $\mathrm{Pt}$, a positive current is associated with the oxidation of adsorbed methanol, influencing the ORR behavior.

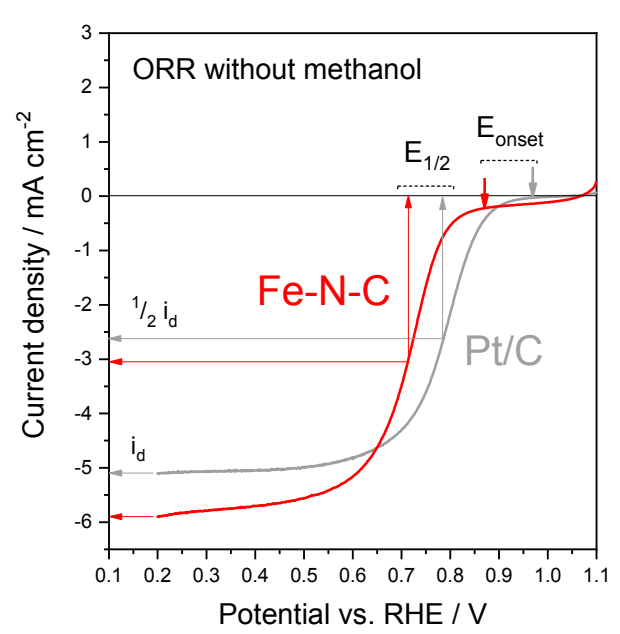

(a)

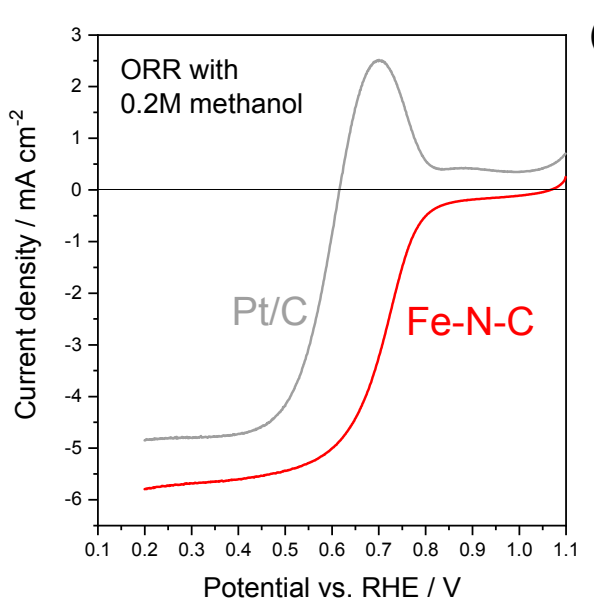

(b)

Figure 1. Typical oxygen reduction reaction (ORR) curves obtained using the rotating disk electrode (RDE) technique. (a) Comparison in the absence of methanol and (b) in the presence of methanol $(0.2 \mathrm{M})$. The Pt/C catalyst was $40 \mathrm{wt} \% \mathrm{Pt} / \mathrm{C}$ from Johnson Matthey, and the platinum-group metal (PGM)-free catalyst was Fe-N-C from reference [44]. All of the curves were obtained in an $\mathrm{O}_{2}$-saturated $0.5 \mathrm{M} \mathrm{H}_{2} \mathrm{SO}_{4}$ aqueous electrolyte, at room temperature, with $50 \mu \mathrm{g} \mathrm{cm}^{-2}$ for Pt and $600 \mu \mathrm{g} \mathrm{cm}^{-2}$ for $\mathrm{Fe}-\mathrm{N}-\mathrm{C}$, and a $5 \mathrm{mV} \mathrm{s}^{-1}$ scan rate at $1600 \mathrm{rpm}$.

Figure 2 shows the onset potential $\left(\mathrm{E}_{\text {onset }}\right)$ and the half wave potential $\left(\mathrm{E}_{1 / 2}\right)$ data, organized according to the most positive onset potential from the left to the right of the histogram. All of the collected papers present the following common points: (1) all of the papers connect the ORR study of the PGM-free catalysts with methanol tolerance experiments; (2) the electrolyte is $\mathrm{HClO}_{4}$ or $\mathrm{H}_{2} \mathrm{SO}_{4}$; and (3) the rotation speed for the RDE experiments is $1600 \mathrm{rpm}$.

On the basis of the data reported in Figure 2, the most active electro-catalyst [47] showed an onset potential $(0.95 \mathrm{~V})$ and $\mathrm{E}_{1 / 2}(0.85 \mathrm{~V})$, very close to the benchmark $\mathrm{Pt} / \mathrm{C}$ in acidic conditions. Moreover, the authors of [47] compared the half wave potential of $\mathrm{Pt} / \mathrm{C}$ and $\mathrm{Cys} 2 / \mathrm{Fe} 0.3 / \mathrm{C}$ in an $\mathrm{O}_{2}$ saturated $0.5 \mathrm{M} \mathrm{H}_{2} \mathrm{SO}_{4}$ electrolyte, containing different methanol concentrations. It appears that the non-PGM catalyst had an excellent methanol tolerance; the most positive $\mathrm{E}_{1 / 2}$ value was observed also with a low methanol concentration in the electrolyte. 


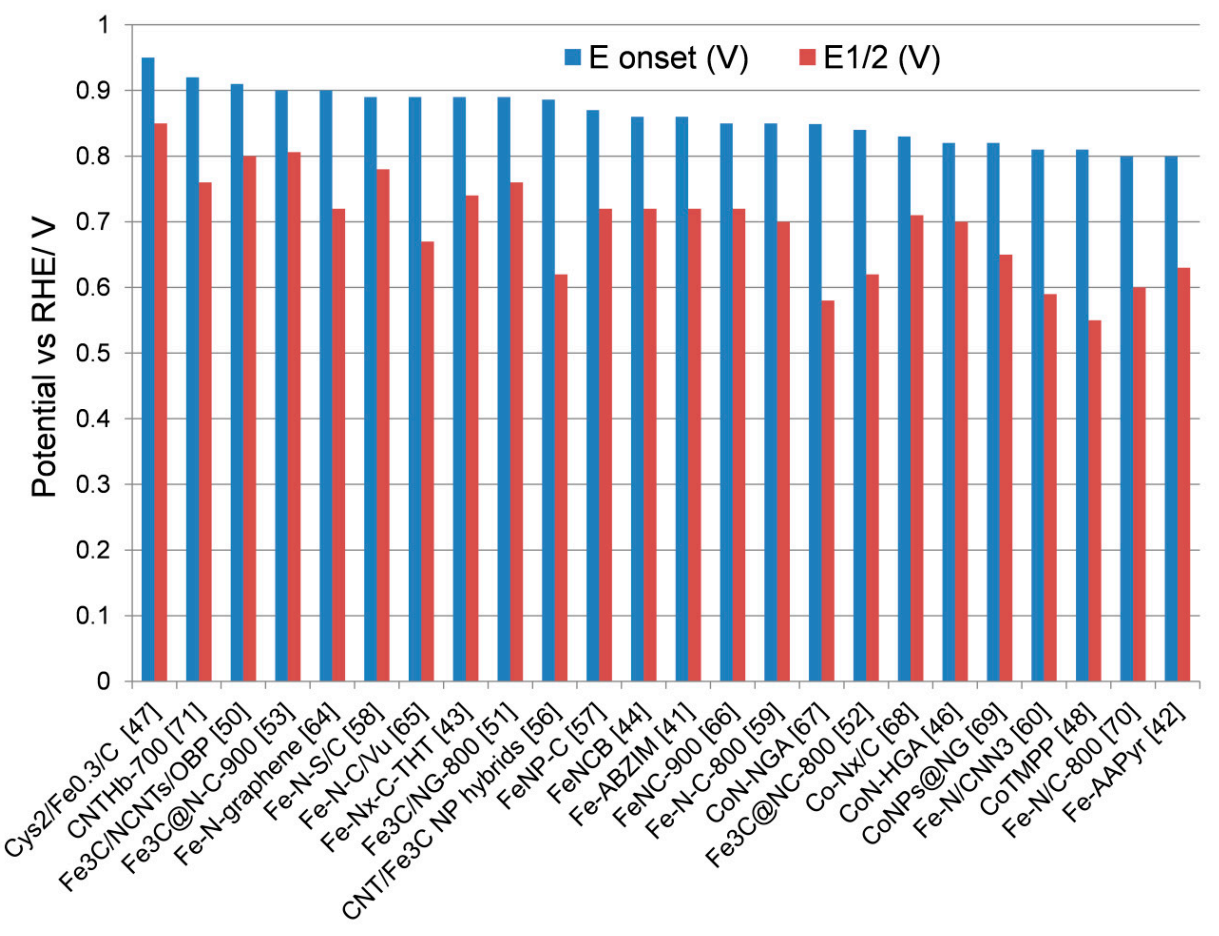

Figure 2. $\mathrm{E}$ onset and $\mathrm{E}_{1 / 2}$ (vs. Reversible Hydrogen Electrode, RHE) of the most recent ORR activity organized in decreasing order of onset potential, from the left to the right of the histogram (experiments at $1600 \mathrm{rpm})$.

The second most positive onset potential $(0.92 \mathrm{~V})$ was related to a metalloprotein $(\mathrm{Hb})$ adsorbed on a carbon nanotube [71]. As in the previous work, $\mathrm{E}_{1 / 2}$ did not change even after a $1 \mathrm{M}$ methanol addition to the electrolyte, revealing a strong methanol tolerance useful for practical applications.

Remarkable results were obtained with $\mathrm{Fe}_{3} \mathrm{C}$-based materials $[50,53]$, showing an onset potential of $0.91 \mathrm{~V}$ [50] and $0.9 \mathrm{~V}$ [53], with $\mathrm{E}_{1 / 2}$ of about $0.8 \mathrm{~V}$ for both catalysts.

A $0.9 \mathrm{~V}$ onset potential was reached using a $\mathrm{Fe}-\mathrm{N}$-graphene compound [64] containing an $\mathrm{N}$-resin precursor, even if the $\mathrm{E}_{1 / 2}$ was slightly lower (0.72) than that obtained with the previously reported catalyst. Here, the excellent methanol tolerance of this catalyst was demonstrated by a chronoamperometric test with the introduction of methanol after $2400 \mathrm{~s}$. Under the same conditions, the current density for $\mathrm{Pt} / \mathrm{C}$ was subjected to a detrimental shift due to the simultaneous methanol oxidation and ORR.

Another very promising electrocatalyst was $\mathrm{Fe}-\mathrm{N}-\mathrm{S} / \mathrm{C}$ [58], with a $0.89 \mathrm{~V}$ onset potential and $0.78 \mathrm{~V}$ half-wave potential. The authors focused their attention on the polarization plot and chronoamperometric response with and without the addition of methanol in the bare electrolyte. Also, in this case, the catalyst showed an excellent methanol tolerance behavior.

By evaluating all of the obtained results summarized in Figure 2, we can derive that the most active electro-catalysts contain iron as a non-noble metal, whereas all of the cobalt-based electrocatalysts, located on the right of the histogram, show a lower activity. From our knowledge, the most active sites for ORR in pyrolysed M-N-C catalysts are single metal-ions strongly coordinated with nitrogen ligands (M-Nx), and these M-Nx moieties are covalently integrated in carbonaceous structures (graphene, CNT, etc.). Moreover, the addition of $S$ is beneficial for ORR activity. It is also useful to remember that the best electrocatalysts derive from a polymer or a metalloprotein, such as the porphyrin or hemoglobin, containing aromatic heterocycles, and ethereal or carboxylates functions. Thus, the overall molecule will be able to perform a specific function at a molecular level, enhancing the electronic conductivity. Furthermore, the best electrocatalysts were prepared using a silica template method, and were characterized by the presence of a larger amount of N-Fe interactions and a smaller amount of 
pyrrolic nitrogen species. Pyridinic sites (known for their high ORR activity, together with graphitic nitrogen) were mainly found in the most performing catalysts. Finally, some authors compared the $\mathrm{M}-\mathrm{N}-\mathrm{C}$ compounds with the metal free nitrogen-carbon counterparts, showing a remarkable increase in the activity thanks to the metal carbide or metal nitrogen active sites.

\subsection{Review of Direct Methanol Fuel Cell Performance with M-N-C Cathode Catalysts}

Table 1 summarizes the recent performance results in DMFC with the acidic membrane of PGM-free catalysts at the cathode electrode, including the catalyst composition, the maximum power density reported, the methanol concentration, and the operating temperature. When several power-to-current curves were reported, we decided to select the most performing data for the sake of comparison. It must be noted that different operating conditions were used and reported in the literature, as there is not a standard protocol for the evaluation of DMFC performance. In this context, it must be considered that increasing the temperature and catalyst loading generally results in a higher performance, while increasing the methanol concentration at the anode can be detrimental due to a crossover effect.

Table 1. Summary of direct methanol fuel cell (DMFC) performances with platinum-group metal (PGM)-free catalysts at the cathode, PtRu at the anode and acidic membrane (Nafion ${ }^{\circledR}$ ).

\begin{tabular}{|c|c|c|c|c|}
\hline Cathode & $\begin{array}{c}\text { Maximum Power } \\
\text { Density } 1 / \mathrm{mW} \mathrm{cm}^{-2}\end{array}$ & $\begin{array}{c}\text { Methanol } \\
\text { Concentration } / \mathrm{mol} \\
\mathrm{L}^{-1}\end{array}$ & Temperature $/{ }^{\circ} \mathrm{C}$ & Reference \\
\hline CoTMPP & 27 & 4.7 & 70 & Olson et al. [48] \\
\hline FeTPP & 28 & 1 & 80 & Serov et al. [45] \\
\hline CoTMPP & 45 & 1.1 & 70 & Piela et al. [49] \\
\hline $\mathrm{Co} / \mathrm{N} / \mathrm{C}$ & 53 & 2 & 60 & Wei et al. [54] \\
\hline $\mathrm{Fe}_{3} \mathrm{C} @ \mathrm{~N}-\mathrm{CNT}$ & 31 & 2 & 60 & Zhu et al. [50] \\
\hline $\mathrm{Fe} / \mathrm{N} / \mathrm{C}$ & 21 & 2 & 50 & Hu et al. [57] \\
\hline $\mathrm{Fe} / \mathrm{N} / \mathrm{C}$ & 20 & 2 & 60 & Xiao et al. [51] \\
\hline $\mathrm{Fe} / \mathrm{N} / \mathrm{C}$ & 15 & 2 & 90 & Negro et al. [60] \\
\hline $\mathrm{Fe} / \mathrm{N} / \mathrm{C}$ & 22 & 10 & 90 & Sebastián et al. [41] \\
\hline $\mathrm{Fe} / \mathrm{N} / \mathrm{C}$ & 60 & 10 & 90 & Sebastián et al. [44] \\
\hline $\mathrm{Fe} / \mathrm{Co}-\mathrm{N}$-graphene & 32 & 10 & 80 & Park et al. [62] \\
\hline $\mathrm{Fe} / \mathrm{N} / \mathrm{C}$ & 20 & 2 & 90 & Osmieri et al. [39] \\
\hline $\mathrm{Fe} / \mathrm{N} / \mathrm{C}$ & 15 & 1 & 70 & Mei et al. [63] \\
\hline $\mathrm{Co} / \mathrm{Zn} / \mathrm{N} / \mathrm{C}$ & 15 & 2 & 90 & Osmieri et al. [40] \\
\hline $\mathrm{Co} / \mathrm{Cu} / \mathrm{N} / \mathrm{C}$ & 13 & 2 & 90 & Osmieri et al. [40] \\
\hline $\mathrm{Fe} / \mathrm{Co} / \mathrm{N} / \mathrm{C}$ & 11 & 2 & 90 & Osmieri et al. [40] \\
\hline $\mathrm{Fe} / \mathrm{Cu} / \mathrm{N} / \mathrm{C}$ & 9 & 2 & 90 & Osmieri et al. [40] \\
\hline $\mathrm{Fe} / \mathrm{Zn} / \mathrm{N} / \mathrm{C}$ & 7.5 & 2 & 90 & Osmieri et al. [40] \\
\hline $\mathrm{Fe} / \mathrm{N} / \mathrm{C}$ & 10.5 & 2 & 90 & Lo Vecchio et al. [61] \\
\hline $\mathrm{Fe} / \mathrm{N} / \mathrm{rGO}$ & 52.5 & 1 & 75 & Li et al. [55] \\
\hline
\end{tabular}

${ }^{1}$ Some values are calculated and/or estimated from the figures reported in each publication.

In 2005, Baranton et al. reported a maximum power density of $6 \mathrm{~mW} \mathrm{~cm}^{-2}$ at a low temperature (close to room temperature), and a $5 \mathrm{M}$ methanol concentration at the anode [37]. As far as we know, this is the very first published result completely removing PGMs from the cathode side in acidic DMFCs. The best PGM-free catalyst was based on a composite of tetrasulphonated iron phtalocyanine and polyaniline. The dispersion in a molecular level of the catalyst was demonstrated to greatly enhance the cathode activity, with a good tolerance to the presence of permeated methanol.

Four years later, Olson and coworkers published a maximum power density of $27 \mathrm{~mW} \mathrm{~cm}{ }^{-2}$, with a cobalt-based catalyst at the cathode, at a higher temperature of $70{ }^{\circ} \mathrm{C}$, and methanol concentrations from 0.28 to $4.7 \mathrm{M}$, with an insignificant variation of voltage-current curves [48]. Almost 
simultaneously, Serov et al. reported DMFC results with a similar power density of $28 \mathrm{~mW} \mathrm{~cm}{ }^{-2}$, using an iron-based catalyst at the cathode [45]. The operating temperature in this case was slightly higher, $80^{\circ} \mathrm{C}$, while the methanol concentration was lower $(1 \mathrm{M})$. The conclusions of these two works were in line with the promising perspectives of the PGM-free catalysts used at the cathode side of this type of fuel cells. Even though less active than $\mathrm{Pt}$, the catalysts derived from metal porphyrins (tetraphenylporphyrin (TPP) or tetramethoxyphenylporphyrin (TMPP)) exhibited interesting features like a high selectivity for ORR in the presence of methanol.

In 2010, Piela and coworkers reported an investigation of a Co-TMPP catalyst for hydrogen-fed polymer electrolyte fuel cells, in which they included DMFC plots at $70{ }^{\circ} \mathrm{C}$ and feeding $1.1 \mathrm{M}$ methanol [49]. They reported a power density of $45 \mathrm{~mW} \mathrm{~cm}^{-2}$ (estimated from the published figure) with this PGM-free catalyst at the cathode side.

An even higher power density was reported by Wei and coworkers in 2012, achieving $58 \mathrm{~mW} \mathrm{~cm}^{-2}$ at $60{ }^{\circ} \mathrm{C}$ and feeding $2 \mathrm{M}$ methanol [54]. In this case, rather than using porphyrins as catalyst precursors, the authors synthesized composites from melamine-formaldehyde aerogels. They concluded that the Fe-based catalysts performed slightly better than the Co ones, but unfortunately, no conclusions were given regarding the characteristics needed for the catalyst to be highly active for the ORR.

Since then, most of the works have been focused on understanding the most important features of the cathode catalyst that favor the DMFC performance and stability, while reducing the cost of the system. It must be considered that the most expensive component, representing $36 \%$ of a DMFC stack cost (mass production of 10,000 units per year), corresponds to the anodic $\mathrm{PtRu} / \mathrm{C}$ catalyst with a Pt loading of $1.2 \mathrm{mg} \mathrm{cm}^{-2}$ [72]. The cost efficiency of the system relies thus on being able to minimize the Pt anode loading. The works discussed in the following paragraphs used anode Pt loadings (using PtRu/C catalysts) below $1.5 \mathrm{mg} \mathrm{cm}^{-2}$, in contrast with previous works with Pt loadings in the interval $2.5-4.0 \mathrm{mg} \mathrm{cm}^{-2}[45,48,49,54]$. As a result, lower performances were obtained because of the sluggishness of the methanol oxidation reaction.

Zhu and coworkers designed a rational design methodology to investigate the variables in the synthesis of $\mathrm{Fe}_{3} \mathrm{C}$ encapsulated into N-doped carbon nanotubes with carbon black [50]. They interestingly concluded that the likelihood of nitrogen participating in the active sites is low, while Fe participates through its electronic effects on carbon.

The doping of $\mathrm{Fe}-\mathrm{N}-\mathrm{C}$ structures with phosphorous was investigated by $\mathrm{Hu}$ and coworkers [57]. They observed a promotional effect of P on the ORR activity, with DMFC performing $21 \mathrm{~mW} \mathrm{~cm} \mathrm{~cm}^{-2}$ at $50{ }^{\circ} \mathrm{C}$ and feeding $2 \mathrm{M}$ methanol. Although far from the DMFC assembled with a commercial Pt catalyst at the cathode (about $80 \mathrm{~mW} \mathrm{~cm}^{-2}$ in the same conditions), they pointed out that the doping with other light elements can contribute to enhancing the cathode activity.

Another important feature is the porous structure of the cathode catalytic layer. A rational design comprising both mesopores and macropores determines the density of the active sites and the mass transport properties. In this sense, Xiao et al. prepared meso-/macro-porous nitrogen-doped carbon architectures with encapsulated $\mathrm{Fe}_{3} \mathrm{C}$ [51]. This catalyst presented a high tolerance to the presence of methanol during ORR, performing $20 \mathrm{~mW} \mathrm{~cm}^{-2}$ at $60{ }^{\circ} \mathrm{C}$. Another interesting approach consisted of synthesizing networked graphitic structures to prepare $\mathrm{Fe} / \mathrm{N} / \mathrm{C}$ catalysts, as reported by Negro and coworkers [60], with a DMFC performance of $15 \mathrm{~mW} \mathrm{~cm}^{-2}$ at $90^{\circ} \mathrm{C}$. Aimed to take advantage of the carbon nanostructures, $\mathrm{Li}$ and collaborators investigated the utilization of reduced graphene oxide as a carbon, with a high surface area and micro-/meso-porous structure, outperforming the activity of Pt at the cathode of DMFC fed with a high methanol concentration [55]. A nanofibrous structure was investigated by Mei and coworkers [63], with maximum power densities in the interval $11-15 \mathrm{~mW} \mathrm{~cm}^{-2}$, depending on the methanol concentration $(1-8 \mathrm{M})$.

Our group, in collaboration with the University of New Mexico, investigated the DMFC performance using $\mathrm{Fe}-\mathrm{N}-\mathrm{C}$ materials at the cathode, prepared from different precursors [41-44]. Clearly, the configuration of the membrane-electrode assembly (MEA) must be optimized to maximize the utilization of the PGM-free catalysts [42]. The high tolerance of these formulations to the presence 
of methanol was evaluated using electrochemical impedance [41] and Density Functional Theory (DFT) calculations [44]. The DFT calculations demonstrated for the first time that $\mathrm{Fe}-\mathrm{N}_{4}$ and $\mathrm{Fe}-\mathrm{N}_{2} \mathrm{C}_{2}$ active sites preferentially adsorb oxygen with a much higher energy than methanol, while nitrogen-carbon related sites (pyridinic and graphitic nitrogen) are much less selective towards ORR [44]. In the DMFC system, water saturation has a dramatic effect on oxygen starvation at the cathode for this typology of $\mathrm{Fe}-\mathrm{N}-\mathrm{C}$ catalysts, as evident from 3D modelling [38]. A biological nitrogen precursor (EDTA) was also investigated by our group to elucidate the best catalyst characteristics, with $\mathrm{Fe}-\mathrm{N}$ interactions, $\mathrm{C}-\mathrm{N}$ defects, and pyridinic nitrogen highly conditioning the performance [61]. Specchia and collaborators have also recently investigated the influence of varying the metal compositions of bimetallic catalysts with interesting synergic effects that may conduct to a further increase in performance [40].

Taking into account all of these discussed aspects together, the PGM-free catalysts appear as a very promising formulation for cost-effective DMFC systems, in which Pt and PGM catalysts can be completely removed from the cathode, and a low loading PtRu catalyst may be employed at the anode. This is summarized in Figure 3, where the maximum power density is represented against the $\mathrm{Pt}$ content in the MEA, considering that it is only present at the anode as a PtRu catalyst. Performances larger than $60 \mathrm{~W} \mathrm{~g}_{\mathrm{Pt}}{ }^{-1}$ can be reached even with a high methanol concentration of $10 \mathrm{M}$, thanks to their extraordinary tolerance to methanol. This means that it is preferred to employ the most expensive metal, $\mathrm{Pt}$, only at the anode, in order to take advantage of the methanol-tolerant properties of $\mathrm{M}-\mathrm{N}-\mathrm{C}$ catalysts at the cathode and to design systems with prolonged operation (high methanol concentration). In fact, they have even shown good performance for DMFC fed with $17 \mathrm{M}$ methanol [60], where the Pt cathode shows a large activation loss. As this value $(17 \mathrm{M})$ is close to the stoichiometric one for the fuel with water, this condition maximizes the system energy capacity.

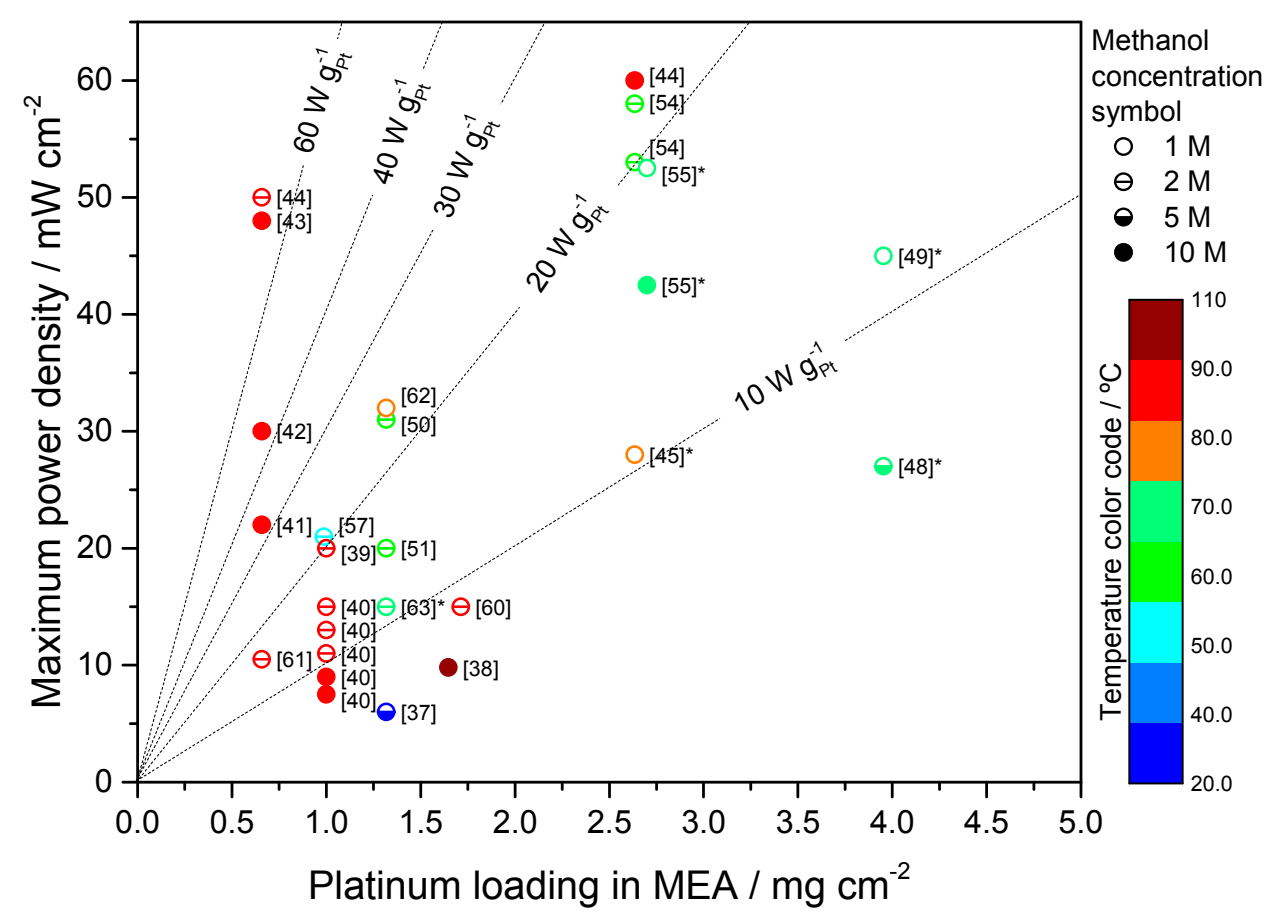

Figure 3. Most recent direct methanol fuel cell (DMFC) performance results using acidic membrane (Nafion ${ }^{\circledR}$ ) and PGM-free catalysts at the cathode. The operating temperature is indicated by colors and the methanol concentration at the anode is depicted by different symbols, as indicated in the legends. Asterisks $\left(^{*}\right)$ reflect that air was used at the cathode instead of oxygen. Dotted lines indicate the different regions as classified by power-to-platinum content. 


\section{Conclusions}

Recent works on non-PGM catalysts based on metal-nitrogen-carbon (M-N-C) have been reviewed for their potential application at the cathode of the DMFCs. Furthermore, their syntheses were analyzed in order to connect the different metal, nitrogen, and carbon sources with their activity for the ORR (in RDE configuration), and their performance and methanol tolerance when deposited at the cathode of a DMFC. There are some analogies between the data obtained in RDE and DMFC; these can be summarized in the following points: (1) until now, iron was the most performing metal in $\mathrm{M}-\mathrm{N}-\mathrm{C}$ catalysts compared to cobalt and nickel; (2) the most suitable nitrogen precursors (porphyrins, phthalocyanines, etc.) contain aromatic conjugated double bonds able to donate electrons to the electropositive metal; (3) a silica template method (SSM) is usually adopted in order to create a meso-/micro-porous hybrid structure; and (4) all of the catalysts show an excellent methanol tolerance.

From the present analysis, it is derived that the most active structures already approach the catalytic activity of Pt-based catalysts in an acidic environment. This fact, together with their extraordinary tolerance to the presence of methanol, makes them very promising candidates for substituting Pt at the cathode of the DMFCs. This kind of catalyst will allow for a strong reduction of cost, with the only need for PGM at the anode side. Moreover, the high tolerance to the presence of permeated methanol permits the operation with much larger methanol concentration at the anode, which in turn means a much prolonged operation of the system, with a clear advantage of the configuration with $\mathrm{M}-\mathrm{N}-\mathrm{C}$ assembled in the DMFCs.

Acknowledgments: D.S. acknowledges the Spanish Ministry of Science, Innovation, and University (MICINN) for his Ramón y Cajal research contract (RyC-2016-20944).

Funding: This research received no external funding.

Conflicts of Interest: The authors declare no conflict of interest.

\section{References}

1. Kimiaie, N.; Wedlich, K.; Hehemann, M.; Lambertz, R.; Korte, C.; Stolten, D. Results of a 20,000 h lifetime test of a $7 \mathrm{~kW}$ direct methanol fuel cell (DMFC) hybrid system-Degradation of the DMFC stack and the energy storage. Energy Environ. Sci. 2014, 7, 3013-3025. [CrossRef]

2. Tiwari, J.N.; Tiwari, R.N.; Singh, G.; Kim, K.S. Recent progress in the development of anode and cathode catalysts for direct methanol fuel cells. Nano Energy 2013, 2, 553-578. [CrossRef]

3. Han, J.; Liu, H. Real time measurements of methanol crossover in a DMFC. J. Power Sources 2007, 164, $166-173$. [CrossRef]

4. Du, C.Y.; Zhao, T.S.; Yang, W.W. Effect of methanol crossover on the cathode behavior of a DMFC: A half-cell investigation. Electrochim. Acta 2007, 52, 5266-5271. [CrossRef]

5. Gurau, B.; Smotkin, E.S. Methanol crossover in direct methanol fuel cells: A link between power and energy density. J. Power Sources 2002, 112, 339-352. [CrossRef]

6. Falcão, D.S.; Oliveira, V.B.; Rangel, C.M.; Pinto, A.M.F.R. Review on micro-direct methanol fuel cells. Renew. Sustain. Energy Rev. 2014, 34, 58-70. [CrossRef]

7. Lamy, C.; Coutanceau, C.; Alonso-Vante, N. Methanol-Tolerant Cathode Catalysts for DMFC. In Electrocatalysis of Direct Methanol Fuel Cells: From Fundamentals to Applications; Liu, H., Zhang, J., Eds.; WILEY-VCH Verlag GmbH \& Co. KGaA: Weinheim, Germany, 2009; pp. 257-314.

8. Calderòn Gómez, J.C.; Moliner, R.; Lázaro, M.J. Palladium-Based Catalysts as Electrodes for Direct Methanol Fuel Cells: A Last Ten Years Review. Catalysts 2016, 6, 130. [CrossRef]

9. Lo Vecchio, C.; Sebastián, D.; Alegre, C.; Aricò, A.S.; Baglio, V. Carbon-supported Pd and Pd-Co cathode catalysts for direct methanol fuel cells (DMFCs) operating with high methanol concentration. J. Electroanal. Chem. 2018, 808, 464-473. [CrossRef]

10. Sebastián, D.; Baglio, V.; Sun, S.; Tavares, A.C.; Aricò, A.S. Graphene-Supported Substoichiometric Sodium Tantalate as a Methanol-Tolerant, Non-Noble-Metal Catalyst for the Electroreduction of Oxygen. ChemCatChem 2015, 2, 911-915. [CrossRef] 
11. Barton, S.C.; Patterson, T.; Wang, E.; Fuller, T.F.; West, A.C. Mixed-reactant, strip-cell direct methanol fuel cells. J. Power Sources 2001, 96, 329-336. [CrossRef]

12. Priestnall, M.A.; Kotzeva, V.P.; Fish, D.J.; Nilsson, E.M. Compact mixed-reactant fuel cells. J. Power Sources 2002, 106, 21-30. [CrossRef]

13. Scott, K.; Shukla, A.K.; Jackson, C.L.; Meuleman, W.R.A. A mixed-reactants solid-polymer-electrolyte direct methanol fuel cell. J. Power Sources 2004, 126, 67-75. [CrossRef]

14. Shao, M. Palladium-based electrocatalysts for hydrogen oxidation and oxygen reduction reactions. J. Power Sources 2011, 196, 2433-2444. [CrossRef]

15. Lo Vecchio, C.; Alegre, C.; Sebastián, D.; Stassi, A.; Aricò, A.S.; Baglio, V. Investigation of supported Pd-based electrocatalysts for the oxygen reduction reaction: Performance, Durability and Methanol Tolerance. Materials 2015, 8, 7997-8008. [CrossRef] [PubMed]

16. Rivera Gavidia, L.M.; Sebastián, D.; Pastor, E.; Aricò, A.S.; Baglio, V. Carbon-Supported Pd and PdFe Alloy Catalysts for Direct Methanol Fuel Cell Cathodes. Materials 2017, 10, 580. [CrossRef] [PubMed]

17. Gago, A.S.; Gochi-ponce, Y.; Feng, Y.; Esquivel, J.P.; Sabaté, N.; Santander, J.; Alonso-Vante, N. Tolerant Chalcogenide Cathodes of Membraneless Micro Fuel Cells. ChemSusChem 2012, 1488-1494. [CrossRef] [PubMed]

18. Li, L.; Liu, S.; Manthiram, A. $\mathrm{Co}_{3} \mathrm{O}_{4}$ nanocrystals coupled with O- and N-doped carbon nanoweb as a synergistic catalyst for hybrid Li-air batteries. Nano Energy 2015, 12, 852-860. [CrossRef]

19. Jahan, M.; Bao, Q.; Loh, K.P. Electrocatalytically active graphene-porphyrin MOF composite for oxygen reduction reaction. J. Am. Chem. Soc. 2012, 134, 6707-6713. [CrossRef] [PubMed]

20. Bull, R.A.; Fan, F.-R.; Bard, A.J. Polymer Films on Electrodes. J. Electrochem. Soc. 2012, 131, 687-690. [CrossRef]

21. Okabayashi, K.; Ikeda, O.; Tamura, H. Electrochemical doping with meso-Tetrakis(4-sulphonatophenyl)porphyrincobalt of a Polypyrrole Film Electrode. J. Chem. Soc. Chem. Commun. 1983, 684-685. [CrossRef]

22. El Hourch, A.; Belcadi, S. Electrocatalytic reduction of oxygen at iron phthalocyanine modified polymer electrodes. J. Electroanal. Chem. 1992, 339, 1-12. [CrossRef]

23. Wu, G.; Santandreu, A.; Kellogg, W.; Gupta, S.; Ogoke, O.; Zhang, H.; Wang, H.L.; Dai, L. Carbon nanocomposite catalysts for oxygen reduction and evolution reactions: From nitrogen doping to transition-metal addition. Nano Energy 2016, 29, 83-110. [CrossRef]

24. Chen, Z.; Higgins, D.; Yu, A.; Zhang, L.; Zhang, J. A review on non-precious metal electrocatalysts for PEM fuel cells. Energy Environ. Sci. 2011, 4, 3167-3192. [CrossRef]

25. Proietti, E.; Jaouen, F.; Lefèvre, M.; Larouche, N.; Tian, J.; Herranz, J.; Dodelet, J.-P. Iron-based cathode catalyst with enhanced power density in polymer electrolyte membrane fuel cells. Nat. Commun. 2011, 2, 416. [CrossRef]

26. Thompson, S.T.; Wilson, A.R.; Zelenay, P.; Myers, D.J.; More, K.L.; Neyerline, K.C.; Papageorgopoulos, D. ElectroCat: DOE's approach to PGM-free catalyst and electrode R \& D. Solid State Ion. 2018, 319, 68-76. [CrossRef]

27. Martinez, U.; Babu, S.K.; Holby, E.F.; Zelenay, P. Durability challenges and perspective in the development of PGM-free electrocatalysts for the oxygen reduction reaction. Curr. Opin. Electrochem. 2018, 9, $224-232$. [CrossRef]

28. Serov, A.; Shum, A.D.; Xiao, X.; De Andrade, V.; Artyushkova, K. Nano-structured platinum group metal-free catalysts and their integration in fuel cell electrode architectures. Appl. Catal. B Environ. 2018, 237, 1139-1147. [CrossRef]

29. Lefèvre, M.; Proietti, E.; Jaouen, F.; Dodelet, J.-P. Iron-Based Catalysts with Improved Oxygen Reduction Activity in Polymer Electrolyte Fuel Cells. Science 2009, 324, 71-74. [CrossRef] [PubMed]

30. Jaouen, F.; Proietti, E.; Lefèvre, M.; Chenitz, R.; Dodelet, J.-P.; Wu, G.; Chung, H.T.; Johnston, C.M.; Zelenay, P. Recent advances in non-precious metal catalysis for oxygen-reduction reaction in polymer electrolyte fuel cells. Energy Environ. Sci. 2011, 4, 114-130. [CrossRef]

31. Serov, A.; Artyushkova, K.; Atanassov, P. Fe-N-C Oxygen Reduction Fuel Cell Catalyst Derived from Carbendazim: Synthesis, Structure, and Reactivity. Adv. Energy Mater. 2014, 4, 1301735. [CrossRef]

32. Chisaka, M.; Ishihara, A.; Ota, K.; Muramoto, H. Synthesis of carbon-supported titanium oxynitride nanoparticles as cathode catalyst for polymer electrolyte fuel cells. Electrochim. Acta 2013, 113, 735-740. [CrossRef] 
33. Ohgi, Y.; Ishihara, A.; Shibata, Y.; Mitsushima, S.; Ota, K. Catalytic Activity of Partially Oxidized Transition-metal Carbide-Nitride for Oxygen Reduction Reaction in Sulfuric Acid. Chem. Lett. 2008, 37, 608-609. [CrossRef]

34. Chisaka, M.; Suzuki, Y.; Iijima, T.; Sakurai, Y. Effect of synthesis route on oxygen reduction reaction activity of carbon-supported hafnium oxynitride in acid media. J. Phys. Chem. C 2011, 115, 20610. [CrossRef]

35. Seifitokaldani, A.; Savadogo, O.; Perrier, M. Stability and catalytic activity of titanium oxy-nitride catalyst prepared by in-situ urea-based sol-gel method for the oxygen reduction reaction (ORR) in acid medium. Int. J. Hydrogen Energy 2015, 40, 10427-10438. [CrossRef]

36. Seifitokaldani, A.; Oishi, K.; Perrier, M.; Savadogo, O. Electrochemical and physicochemical properties of titanium Oxy-nitride electrocatalyst prepared by sol-gel methods for the oxygen reduction reaction purposes. J. Solid State Electrochem. 2015, 19, 3097-3109. [CrossRef]

37. Baranton, S.; Coutanceau, C.; Léger, J.-M.; Roux, C.; Capron, P. Alternative cathodes based on iron phthalocyanine catalysts for mini- or micro-DMFC working at room temperature. Electrochim. Acta 2005, 51, 517-525. [CrossRef]

38. Monteverde Videla, A.H.A.; Sebastián, D.; Vasile, N.S.; Osmieri, L.; Aricò, A.S.; Baglio, V.; Specchia, S. Performance analysis of Fe-N-C catalyst for DMFC cathodes: Effect of water saturation in the cathodic catalyst layer. Int. J. Hydrogen Energy 2016, 41, 22605-22618. [CrossRef]

39. Osmieri, L.; Escudero-Cid, R.; Monteverde Videla, A.H.A.; Ocón, P.; Specchia, S. Performance of a Fe-N-C catalyst for the oxygen reduction reaction in direct methanol fuel cell: Cathode formulation optimization and short-term durability. Appl. Catal. B Environ. 2017, 201, 253-265. [CrossRef]

40. Osmieri, L.; Escudero-Cid, R.; Armandi, M.; Ocón, P.; Monteverde Videla, A.H.A.; Specchia, S. Effects of using two transition metals in the synthesis of non-noble electrocatalysts for oxygen reduction reaction in direct methanol fuel cell. Electrochim. Acta 2018, 266, 220-232. [CrossRef]

41. Sebastián, D.; Serov, A.; Artyushkova, K.; Atanassov, P.; Aricò, A.S.; Baglio, V. Performance, methanol tolerance and stability of Fe-aminobenzimidazole derived catalyst for direct methanol fuel cells. J. Power Sources 2016, 319, 235-246. [CrossRef]

42. Sebastián, D.; Baglio, V.; Aricò, A.S.; Serov, A.; Atanassov, P. Performance analysis of a non-platinum group metal catalyst based on iron-aminoantipyrine for direct methanol fuel cells. Appl. Catal. B Environ. 2016, 182, 297-305. [CrossRef]

43. Sebastián, D.; Serov, A.; Artyushkova, K.; Gordon, J.; Atanassov, P.; Aricò, A.S.; Baglio, V. High Performance and Cost-Effective Direct Methanol Fuel Cells: Fe-N-C Methanol-Tolerant Oxygen Reduction Reaction Catalysts. ChemSusChem 2016, 9, 1986-1995. [CrossRef] [PubMed]

44. Sebastián, D.; Serov, A.; Matanovic, I.; Artyushkova, K.; Atanassov, P.; Aricò, A.S.; Baglio, V. Insights on the extraordinary tolerance to alcohols of Fe-N-C cathode catalysts in highly performing direct alcohol fuel cells. Nano Energy 2017, 34, 195-204. [CrossRef]

45. Serov, A.A.; Min, M.; Chai, G.; Han, S.; Seo, S.J.; Park, Y.; Kim, H.; Kwak, C. Electroreduction of oxygen over iron macrocyclic catalysts for DMFC applications. J. Appl. Electrochem. 2009, 39, 1509-1516. [CrossRef]

46. Kong, W.; Yao, K.; Duan, X.; Liu, Z.; Hu, J. Holey Co, N-codoped graphene aerogel with in-plane pores and multiple active sites for efficient oxygen reduction. Electrochim. Acta 2018, 269, 544-552. [CrossRef]

47. Kwak, D.-H.; Han, S.-B.; Kim, D.-H.; Won, J.-E.; Park, K.-W. Amino acid-derived non-precious catalysts with excellent electrocatalytic performance and methanol tolerance in oxygen reduction reaction. Appl. Catal. B Environ. 2018, 238, 93-103. [CrossRef]

48. Olson, T.S.; Blizanac, B.; Piela, B.; Davey, J.R.; Zelenay, P.; Atanassov, P. Electrochemical Evaluation of Porous Non-Platinum Oxygen Reduction Catalysts for Polymer Electrolyte Fuel Cells. Fuel Cells 2009, 9, 547-553. [CrossRef]

49. Piela, B.; Olson, T.S.; Atanassov, P.; Zelenay, P. Highly methanol-tolerant non-precious metal cathode catalysts for direct methanol fuel cell. Electrochim. Acta 2010, 55, 7615-7621. [CrossRef]

50. Zhu, J.; Xiao, M.; Liu, C.; Ge, J.; St-Pierre, J.; Xing, W. Growth mechanism and active site probing of $\mathrm{Fe}_{3} \mathrm{C} @ \mathrm{~N}-$ doped carbon nanotubes/C catalysts: Guidance for building highly efficient oxygen reduction electrocatalysts. J. Mater. Chem. A 2015, 3, 21451-21459. [CrossRef]

51. Xiao, M.; Zhu, J.; Feng, L.; Liu, C.; Xing, W. Meso/macroporous nitrogen-doped carbon architectures with iron carbide encapsulated in graphitic layers as an efficient and robust catalyst for the oxygen reduction reaction in both acidic and alkaline solutions. Adv. Mater. 2015, 27, 2521-2527. [CrossRef] 
52. Yang, X.; Hu, X.; Wang, X.; Fu, W.; He, X.; Asefa, T. Metal-organic framework-derived Fe 3 C@NC nanohybrids as highly-e ffi cient oxygen reduction electrocatalysts in both acidic and basic media. J. Electroanal. Chem. 2018, 823, 755-764. [CrossRef]

53. Liu, Y.-L.; Xu, X.-Y.; Sun, P.-C.; Chen, T.-H. N-doped porous carbon nanosheets with embedded iron carbide nanoparticles for oxygen reduction reaction in acidic media. Int. J. Hydrogen Energy 2015, 40, 4531-4539. [CrossRef]

54. Wei, Y.; Shengzhou, C.; Weiming, L. Oxygen reduction on non-noble metal electrocatalysts supported on N-doped carbon aerogel composites. Int. J. Hydrogen Energy 2012, 37, 942-945. [CrossRef]

55. Li, Q.; Wang, T.; Havas, D.; Zhang, H.; Xu, P.; Han, J.; Cho, J.; Wu, G. High-Performance Direct Methanol Fuel Cells with Precious-Metal-Free Cathode. Adv. Sci. 2016, 3, 1-9. [CrossRef] [PubMed]

56. Yang, W.; Liu, X.; Yue, X.; Jia, J.; Guo, S. Bamboo-like Carbon Nanotube/ $\mathrm{Fe}_{3} \mathrm{C}$ Nanoparticle Hybrids and Their Highly Efficient Catalysis for Oxygen Reduction. J. Am. Chem. Soc. 2015, 137, 1436-1439. [CrossRef] [PubMed]

57. Hu, Y.; Zhu, J.; Lv, Q.; Liu, C.; Li, Q.; Xing, W. Promotional effect of phosphorus doping on the activity of the Fe-N/C catalyst for the oxygen reduction reaction. Electrochim. Acta 2015, 155, 335-340. [CrossRef]

58. Qiu, Q.; Yang, W.; Zhan, Y.; Wang, H. Facile synthesis of high performance non-noble-metal electrocatalyst Fe-N-S/C for oxygen reduction reaction in acidic solutions. J. Mater. Sci. Mater. Electron. 2017, 28, 949-957. [CrossRef]

59. Lo Vecchio, C.; Aricò, A.S.; Monforte, G.; Baglio, V. EDTA-derived Co-N-C and Fe-N-C electro-catalysts for the oxygen reduction reaction in acid environment. Renew. Energy 2018, 120, 342-349. [CrossRef]

60. Negro, E.; Videla, A.H.A.M.; Baglio, V.; Aricò, A.S.; Specchia, S.; Koper, G.J.M. Fe-N supported on graphitic carbon nano-networks grown from cobalt as oxygen reduction catalysts for low-temperature fuel cells. Appl. Catal. B Environ. 2015, 166-167, 75-83. [CrossRef]

61. Lo Vecchio, C.; Aricò, A.; Baglio, V.; Lo Vecchio, C.; Aricò, A.S.; Baglio, V. Application of Low-Cost Me-N-C $(\mathrm{Me}=\mathrm{Fe}$ or $\mathrm{Co})$ Electrocatalysts Derived from EDTA in Direct Methanol Fuel Cells (DMFCs). Materials 2018, 11, 1193. [CrossRef]

62. Park, J.C.; Choi, C.H. Graphene-derived Fe/Co-N-C catalyst in direct methanol fuel cells: Effects of the methanol concentration and ionomer content on cell performance. J. Power Sources 2017, 358, 76-84. [CrossRef]

63. Mei, R.; Xi, J.; Ma, L.; An, L.; Wang, F.; Sun, H.; Luo, Z.; Wu, Q. Multi-Scaled Porous Fe-N/C Nanofibrous Catalysts for the Cathode Electrodes of Direct Methanol Fuel Cells. J. Electrochem. Soc. 2017, 164, F1556-F1565. [CrossRef]

64. He, C.; Zhang, J.J.; Shen, P.K. Nitrogen-self-doped graphene-based non-precious metal catalyst with superior performance to $\mathrm{Pt} / \mathrm{C}$ catalyst toward oxygen reduction reaction. J. Mater. Chem. A 2014, 2, 3231-3236. [CrossRef]

65. Bukola, S.; Merzougui, B.; Akinpelu, A.; Laoui, T.; Hedhili, M.N.; Swain, G.M.; Shao, M. Fe-N-C Electrocatalysts for Oxygen Reduction Reaction Synthesized by Using Aniline Salt and $\mathrm{Fe}^{3+} / \mathrm{H}_{2} \mathrm{O}_{2}$ Catalytic System. Electrochim. Acta 2014, 146, 809-818. [CrossRef]

66. Zuo, Q.; Zhao, P.; Luo, W.; Cheng, G. Hierarchically porous Fe-N-C derived from covalent-organic materials as a highly efficient electrocatalyst for oxygen reduction. Nanoscale 2016, 8, 14271-14277. [CrossRef] [PubMed]

67. Yao, Y.; Lin, X.; Zhang, X. Cobalt nitride nanoparticle-modified nitrogen-doped graphene aerogel used as an efficient catalyst for oxygen reduction reaction in acidic medium. J. Mater. Sci. 2018, 53, 7691-7702. [CrossRef]

68. Wei, J.; Hu, Y.; Wu, Z.; Liang, Y.; Leong, S.; Kong, B.; Zhang, X.; Zhao, D.; Simon, G.P.; Wang, H. A graphene-directed assembly route to hierarchically porous $\mathrm{Co}-\mathrm{Nx} / \mathrm{C}$ catalysts for high-performance oxygen reduction. J. Mater. Chem. 2015, 3, 16867-16873. [CrossRef]

69. Lv, L.-B.; Ye, T.-N.; Gong, L.-H.; Wang, K.-X.; Su, J.; Li, X.-H.; Chen, J.-S. Anchoring Cobalt Nanocrystals through the Plane of Graphene: Highly Integrated Electrocatalyst for Oxygen Reduction Reaction. Chem. Mater. 2015, 27, 544-549. [CrossRef]

70. Lin, L.; Zhu, Q.; Xu, A.-W. Noble-Metal-Free Fe-N/C Catalyst for Highly Efficient Oxygen Reduction Reaction under Both Alkaline and Acidic Conditions. J. Am. Chem. Soc. 2014, 136, 11027-11033. [CrossRef] 
71. Vij, V.; Tiwari, J.N.; Lee, W.-G.; Yoon, T.; Kim, K.S. Hemoglobin-carbon nanotube derived noble-metal-free $\mathrm{Fe}_{5} \mathrm{C}_{2}$-Based catalyst for highly efficient oxygen reduction reaction. Sci. Rep. 2016, 6, 20132. [CrossRef]

72. Sgroi, M.F.; Zedde, F.; Barbera, O.; Stassi, A.; Sebastián, D.; Lufrano, F.; Baglio, V.; Aricò, A.S.; Bonde, J.L.; Schuster, M. Cost Analysis of Direct Methanol Fuel Cell Stacks for Mass Production. Energies 2016, 9, 1008. [CrossRef] 